University of Nebraska - Lincoln

DigitalCommons@University of Nebraska - Lincoln

National Invasive Species Council materials Wildlife Damage Management, Internet Center

\title{
Length-Weight Relationships for Three Asian Carp Species in the Missouri River
}

\author{
Greg A. Wanner \\ U.S. Fish and Wildlife Service, Greg_Wanner@fws.gov \\ Robert A. Klumb \\ U.S. Fish and Wildlife Service
}

Follow this and additional works at: https://digitalcommons.unl.edu/natlinvasive

Part of the Environmental Indicators and Impact Assessment Commons

Wanner, Greg A. and Klumb, Robert A., "Length-Weight Relationships for Three Asian Carp Species in the Missouri River" (2009). National Invasive Species Council materials. 31.

https://digitalcommons.unl.edu/natlinvasive/31

This Article is brought to you for free and open access by the Wildlife Damage Management, Internet Center for at DigitalCommons@University of Nebraska - Lincoln. It has been accepted for inclusion in National Invasive Species Council materials by an authorized administrator of DigitalCommons@University of Nebraska - Lincoln. 


\title{
Length-Weight Relationships for Three Asian Carp Species in the Missouri River \\ Greg A. Wanner and Robert A. Klumb \\ U.S. Fish and Wildlife Service, Great Plains Fish and Wildlife Conservation Office 420 South Garfield Avenue, Suite 400 \\ Pierre, South Dakota 57501 USA
}

\author{
E-mail: Greg_Wanner@tws.gov
}

\begin{abstract}
Bighead carp (Hypophthalmichthys nobilis), silver carp (Hypophthalmichthys molitrix), and grass carp (Ctenopharyngodon idella), collectively referred to as Asian carp, are invasive species that have been introduced into the Mississippi River basin. The expansion of Asian carp into the Missouri River is not well understood and knowledge of population characteristics within this river are lacking. The objectives of this study were to describe the length-weight relationships (condition) of Asian carp from 2003 to 2007 in the Missouri River downstream of Gavins Point Dam, South Dakota and Nebraska to St. Louis, Missouri. All total, 388 bighead, 75 silver, and 111 grass carp were measured and weighed. Short bighead carp weighed significantly less in the upper Missouri River from Gavins Point Dam to the Platte River compared to fish of the lower Missouri River from the Grand River to the Mississippi River. Conversely, long bighead carp in the upper Missouri River attained greater weights than fish of similar length downstream. Though not significant, condition similarly varied between the upper and lower Missouri River for silver carp and grass carp.
\end{abstract}

\section{INTRODUCTION}

Asian carp were introduced to the United States as a biological tool by natural resource agencies and aquaculturists. Bighead carp (Hypophthalmichthys nobilis) and silver carp (Hypophthalmichthys molitrix) were first introduced to a private fish farm in Arkansas in 1972 to improve water quality (Conover et al. 2007). Later in the 1970's bighead and silver carp were researched by natural resource agencies and aquaculturists to improve water quality in lakes, aquaculture ponds, and wastewater systems. By the early 1980's bighead and silver carp appeared in Arkansas rivers (Freeze and Henderson 1982), and evidence of natural reproduction was found in the Missouri River in 1989 (Kolar et al. 2005). Bighead carp are also sold live as a food fish in specialty ethnic markets (Kolar et al. 2005); however, silver carp are not cultured in the United States and are now listed under the "injurious wildlife provision" of the Lacey Act (Fowler et al. 2007). Because both bighead and silver carp feed on plankton, they may have adverse affects on native fish, mussels, and zooplankton at all life stages. Schrank et al. (2003) reported dietary overlap between age-0 bighead carp and paddlefish (Polyodon spathula) in laboratory studies. Sampson et al. (2009) reported bighead carp dietary overlap with gizzard shad (Dorosoma cepedianum) and bigmouth buffalo (Ictiobus cyprinellus) in the Illinois River and Mississippi River, and condition of these two native species has declined since establishment of Asian carp (Irons et al. 2007).

The grass carp (Ctenopharyngodon idella) was introduced to the United States by federal and state researchers to investigate biological controls of aquatic vegetation (Avault 1965, Mitchell and Kelly 2006). Natural resource agencies and private pond owners have distributed grass carp throughout the United States starting in the 1970's (Pflieger 1978, Guillory and Gasaway 1978). Triploid carp are authorized for stocking in 38 states, while an additional 10 states allow diploids to be stocked (Dauwalter and Jackson 2005). The grass carp has the potential to alter habitats, affect native communities through competition with other fish and invertebrates, disrupt food webs, and increase eutrophication (Conover et al. 2007). 
The establishment of Asian carp in the Missouri River could potentially cause great ecological harm. Asian carp are mobile, long-lived, tolerate a broad range of climates, have opportunistic food habits, and have high reproductive capabilities, population densities, and growth rates (Cudmore and Mandrak 2004, Kolar et al. 2005). Mean fecundity of female bighead carp in the Missouri River was 226,213 eggs, and bimodal egg diameters in the ovary indicated potential for protracted spawning (Shrank and Guy 2002). The silver carp also has protracted spawning periods with some fish spawning multiple times within a year (Papoulias et al. 2006). By age-3, bighead carp and silver carp can attain total lengths $>500 \mathrm{~mm}$ (Johal et al. 2001, Shrank and Guy 2002), which likely precludes these species from predation by native Missouri River piscivores. With these life history traits, Asian carp will likely change the aquatic environment, to the detriment of native aquatic organisms.

Further understanding of Asian carp population characteristics such as condition is critical to their management and control in the Missouri River. Length and weight measurements are cornerstones of fisheries management and research (Anderson and Neumann 1996) and can be used to describe the condition of fish. Fish in good condition are expected to have fast growth rates, high reproductive potential, and/or high survival (Anderson and Neumann 1996), which indicates favorable habitat conditions and ample prey availability (Blackwell et al. 2000). As Asian carp continue to expand their range, increase in abundance (Chick and Pegg 2001), and potentially compete with other native planktivores (Schrank et al. 2003, Sampson et al. 2009), it is increasingly important to understand the condition of Asian carp in the Missouri River. Therefore, the objective of this study was to describe the length-weight relationships (i.e., condition) of the three Asian carp species in the Missouri River and investigate differences in condition among different reaches of the river.

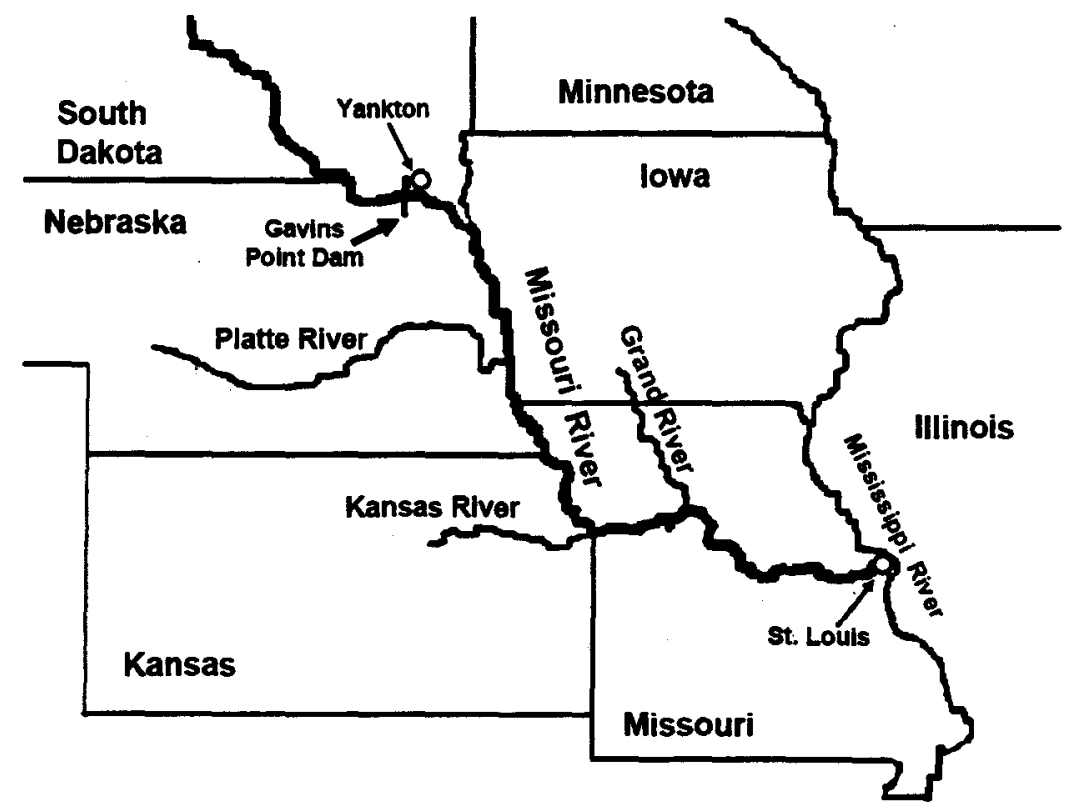

Figure 1. The Missouri River from Gavins Point Dam (rkm 1,305) to its confluence with the Mississippi River ( $\mathrm{rkm} 0$ ). The Gavins Point reach extends from Gavins Point Dam to the confluence of the Platte River (rkm 958), Platte-Kansas reach extends from the Platte River to the Grand River confluence (rkm 250), and the Interior Highlands extends from the Grand River to the Missouri River mouth. 
METHODS AND MATERIALS

Asian carp were collected during three Missouri River monitoring programs from 2003 to 2007. Gears that captured Asian carp included overnight gill, hoop, and minifyke nets, drifted trammel nets, towed or pushed trawls, and electrofishing. Detailed guidelines for gear specifications, deployment methods, and data collection were described in Drobish (2008) and Wanner et al. (2007). All Asian carp were measured to total length (TL; $\mathrm{mm}$ ) and weighed to the nearest $\mathrm{g}$.

Our study area was the Missouri River from Gavins Point Dam near Yankton, South Dakota (river kilometer [rkm] 1,305) to its confluence with the Mississippi River near St. Louis, Missouri (rkm 0) (Fig. 1). Gavins Point Dam is the farthest downstream mainstem dam on the Missouri River, and to date no Asian carp have been captured in the Missouri River upstream of this barrier (Shuman et al. 2008). The Missouri River was divided into three reaches based on hydrological characteristics and large tributary influences. The "Gavins Point" reach extends from Gavins Point Dam to the confluence of the Platte River (rkm 958). This reach is highly influenced by an unnatural hydrograph due to releases from Gavins Point Dam. The "Platte-Kansas" reach extends from the Platte River to the Grand River confluence (rkm 250) and is highly influenced from the effects of large tributaries, which flow across highly erodible lands and carry high sediment loads into the Missouri River. The farthest downstream reach from the Grand River confluence to the Missouri River mouth has a more natural hydrograph due to tributary discharges and distance from Gavins Point Dam and herein is defined as the "Interior Highlands" reach based on the physiographic provinces of Cross et al. (1986). Length-weight comparisons were made only between the Gavins Point (upstream) and Interior Highlands (downstream) reaches because there was a minimal number of Asian carp weighed in the Platte-Kansas reach.

Linear regression was used to describe the $\log _{10}$ length- $\log _{10}$ weight relationship for each species of Asian carp. Analysis of covariance (ANCOVA) was also used to assess potential differences in condition between the two reaches for each Asian carp species with $\log _{10}$ length set as the covariate. A general linear model (Hintz 2006) was first run, in which the dependent variable ( $\log _{10}$ weight) was modeled as a function of the treatment variable (reach), covariate ( $\log _{10}$ length), and their interaction. The interaction term tested for homogeneity of slopes, and, if not significant, the reduced model (without the interaction) was run to test for differences in the intercepts. If the treatment variable was not significant, then intercepts were not different and would suggest that the Asian carp in the two river reaches gained weight incrementally with increasing length in a similar fashion.

\section{RESULTS AND DISCUSSION}

Similar ranges of lengths and weights of bighead $(322-1,200 \mathrm{~mm}$ and $452-$ $19,336 \mathrm{~g})$ and grass carp (307 - 1,080 $\mathrm{mm}$ and $330-12,965 \mathrm{~g})$ were compared between the Gavins Point and Interior Highlands reaches. Silver carp ranged from 231 to $880 \mathrm{~mm}$ $\mathrm{TL}$ and 104 to $8,640 \mathrm{~g}$. Only seven silver carp were measured and weighed in the Gavins Point reach, and they were substantially smaller $(21 \%$ in mean TL and $43 \%$ in mean weight) compared to the 68 fish captured in the Interior Highlands reach. Despite the collective use of 25 types of fish sampling gear deployed by three large monitoring programs in the Missouri River from $2003-2007,<1,400$ individuals of each Asian carp species were collected (Wanner and Klumb 2009). Asian carp are wary to capture which impedes our ability to describe their relative abundance (U.S. Fish and Wildlife Service 2003, Conover et al. 2007). Although sufficient numbers of Asian carp were captured for condition analyses, weight measurements were not routinely collected which further limited our sample size. In areas where Asian carp are expanding their range, we recommend routine measurements of length and weight be done for Asian carp as well as 
native fish species with similar feeding habits to facilitate analyses of condition to assess competitive interactions (Irons et al. 2007, Sampson et al. 2009).

The relationship between $\log _{10}$ length- $\log _{10}$ weight in the two reaches of the Missouri River was significant for each Asian carp species (Table 1, Fig. 2). Based on ANCOVA, $\log _{10}$ length was a significant covariate affecting $\log _{10}$ weight of bighead carp differently in the Gavins Point and Interior Highlands reaches $(\mathrm{F}=4.58$, df $1,384, \mathrm{P}=$ $0.033)$. $\log _{10}$ length was not a significant covariate for silver carp $(F=2.65$, df $1,71, P=$ $0.108)$ and grass carp $(\mathrm{F}=0.42$, $\mathrm{df} 1,107, \mathrm{P}=0.518)$. Additionally, intercepts were not significantly different between river reaches for both silver carp $(\mathrm{F}=0.06, \mathrm{df} 1,72, \mathrm{P}=$ $0.806)$ and grass carp $(F=3.09, \mathrm{df} 1,108, \mathrm{P}=0.081)$. Therefore, silver carp and grass carp in the Gavins Point and Interior Highlands reaches gained weight incrementally in a similar fashion. However, bighead carp at shorter lengths attained less weight (lower condition) in the Gavins Point reach compared to downstream in the Interior Highlands reach. Conversely, condition of long bighead carp in the Gavins Point reach was higher compared to fish in the Interior Highlands reach. Although not significant, this same trend of lowered condition for short fish and high condition for long fish in the Gavins Point reach was observed for silver carp and grass carp.

Differences in weight at a given length for bighead carp significantly differed between the two reaches. Wanner and Klumb (2009) reported that more young of the year Asian carp were found in the Interior Highlands reach. Given the higher weights for short fish and their high relative abundance, this may suggest that there was a greater availability of food for small Asian carp in the Interior Highlands reach. Increased condition may also indicate that better habitat conditions (Blackwell et al. 2000) were available for small Asian carp compared to farther upstream in the Missouri River. Differences in silver carp condition may not have been detected due to low sample size, whereas grass carp condition did not vary between reaches because their preferred food of macrophytes is not common throughout the Missouri River (Galat et al. 2005).

Gonadal development, especially given the high biomass of eggs in female Asian carp (Shrank and Guy 2002; Williamson and Garvey 2005), will affect relative condition of fish. Although fish were not identified by sex and condition was not analyzed by season (Blackwell et al. 2000) during this study, more female fish may have been measured in our samples. Asian carp may have moved upstream into the Gavins Point reach during spawning, which may explain the high relative condition for large fish in

Table 1. Linear regression analysis comparing the $\log _{10}$ length- $\log _{10}$ weight relationships for three Asian carp species in an upstream reach (Gavins Point) and downstream reach (Interior Highlands) of the Missouri River captured from 2003 to 2007. All regressions were significant $(\mathrm{P}<0.001)$.

\begin{tabular}{|c|c|c|c|c|c|}
\hline Reach & Estimated model & $\mathrm{N}$ & $r^{2}$ & $\begin{array}{c}\text { Intercept } \\
95 \% \mathrm{CI}\end{array}$ & $\begin{array}{c}\text { Slope } \\
95 \% \mathrm{CI}\end{array}$ \\
\hline \multicolumn{6}{|c|}{ Bighead carp } \\
\hline Gavins Point & $\log _{10}$ weight $=-4.86+2.96\left(\log _{10}\right.$ length $)$ & 224 & 0.98 & 0.17 & 0.06 \\
\hline Interior Highlands & $\log _{10}$ weight $=-4.30+2.75\left(\log _{10}\right.$ length $)$ & 164 & 0.80 & 0.61 & 0.21 \\
\hline \multicolumn{6}{|c|}{ Silver carp } \\
\hline Gavins Point & $\log _{10}$ weight $=-6.92+3.70\left(\log _{10}\right.$ length $)$ & 7 & 0.97 & 2.08 & 0.76 \\
\hline Interior Highlands & $\log _{10}$ weight $=-5.35+3.13\left(\log _{10}\right.$ length $)$ & 68 & 0.93 & 0.59 & 0.21 \\
\hline \multicolumn{6}{|c|}{ Grass carp } \\
\hline Gavins Point & $\log _{10}$ weight $=-4.59+2.87\left(\log _{10}\right.$ length $)$ & 33 & 0.97 & 0.55 & 0.19 \\
\hline Interior Highlands & $\log _{10}$ weight $=-4.33+2.77\left(\log _{10}\right.$ length $)$ & 78 & 0.88 & 0.69 & 0.24 \\
\hline
\end{tabular}


this reach. Schrank and Guy (2002) reported the relationship between weight and length was highly similar between male and female bighead carp in the Missouri River; however, their sampling was not conducted during the peak spawning period, which precluded comparisons of condition between sexes of ripe fish.

Bighead and silver carp will likely have adverse affects on all life stages of native species because they feed on plankton, the primary food source of several adult fish (Irons et al. 2007, Sampson et al. 2009), larval fish (Schrank et al. 2003), and mussels (Kolar et al. 2007). Grass carp adversely modify preferred fish habitats, disrupt food webs, and modify trophic structure (Conover et al. 2007). As Asian carp continue to increase in abundance and invade new waters (Peters et al. 2006, Wanner and Klumb 2009), it is increasingly critical to understand Asian carp population characteristics such as condition.

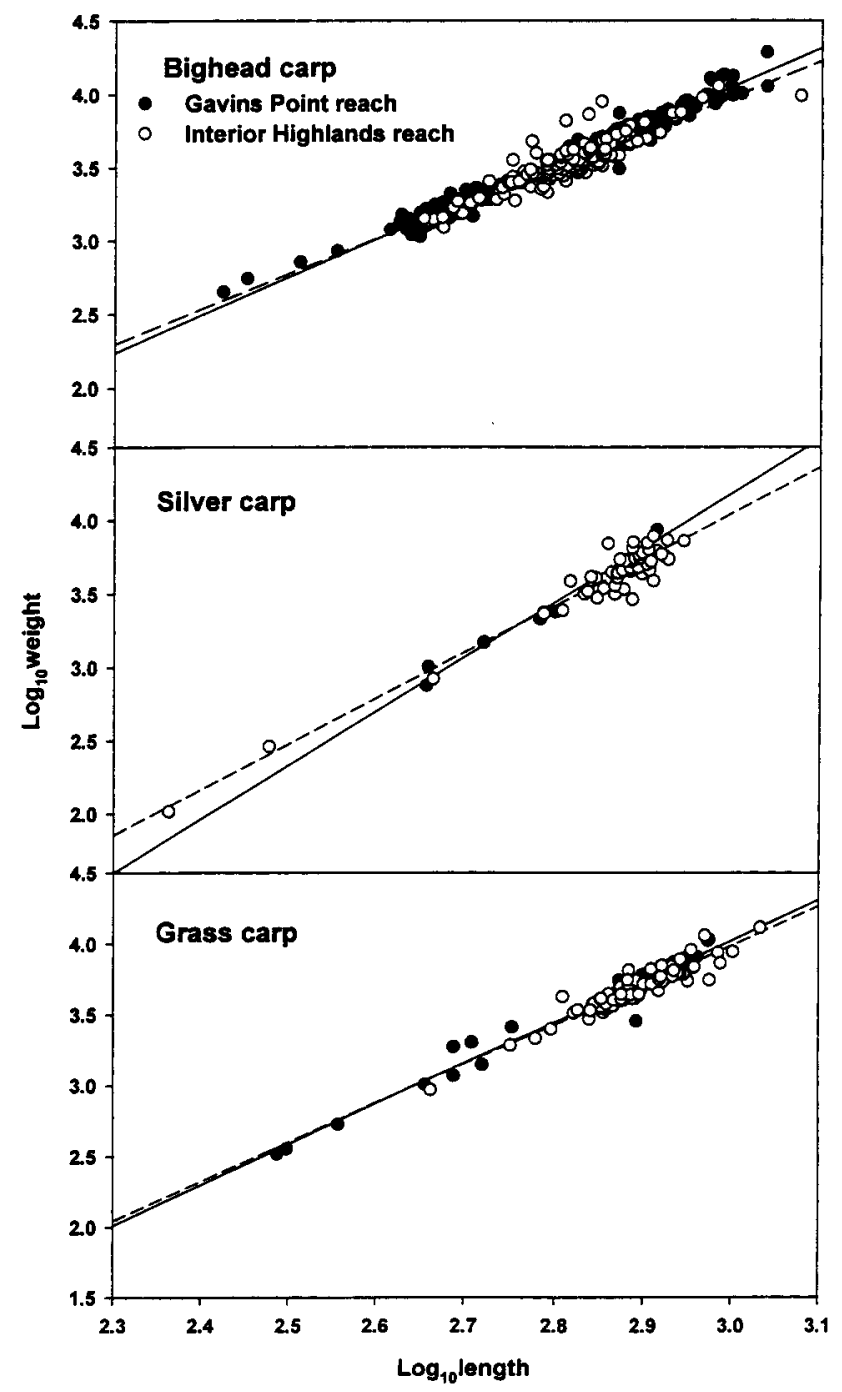

Figure 2. Weight-length relationship of bighead carp, silver carp, and grass carp captured from 2003 to 2007 in upstream (Gavins Point) and downstream (Interior Highlands) reaches of the Missouri River. Lines indicate model fits for the Gavins reach (solid line) and Interior Highlands reach (dashed line). 


\section{ACKNOWLEDGEMENTS}

We thank field crews from the South Dakota Department of Game, Fish and Parks, Nebraska Game and Parks Commission, Iowa Department of Natural Resources, Missouri Department of Conservation (MDC), U.S. Fish and Wildlife Service, Columbia National Fish and Wildlife Conservation Office, and the U.S. Army Corps of Engineers. We also thank the database managers at MDC in Chillicothe, Missouri for entering and preparing the data. Funding for the three Missouri River monitoring programs was provided by the U.S. Army Corps of Engineers and the Aquatic Nuisance Species Coordinator for the U.S. Fish and Wildlife Service-Region 6, Lakewood, Colorado.

\section{LITERATURE CITED}

Anderson, R. O. and R. M. Neumann. 1996. Length, weight, and associated structural indices. Pages 447 - 482 In: Murphy, B. R. and D. W. Willis (eds.), Fisheries techniques, $2^{\text {nd }}$ edition. American Fisheries Society, Bethesda, Maryland.

Avault, J. W., Jr. 1965. Preliminary studies with grass carp for aquatic weed control. The Progressive Fish-Culturist 27:207-209.

Blackwell, B. G., M. L. Brown, and D. W. Willis. 2000. Relative weight (Wr) status and current use in fisheries assessment and management. Reviews in Fisheries Science 8:1-44.

Chick, J. H. and M. A. Pegg. 2001. Invasive carp in the Mississippi River basin. Science 292:2250-2251.

Conover, G., R. Simmonds, and M. Whalen (eds.). 2007. Management and control plan for bighead, black, grass, and silver carps in the United States. Asian Carp Working Group, Aquatic Nuisance Species Task Force, Washington D. C. 223 pp.

Cross, F. B., R. L. Mayden, and J. D. Stewart. 1986. Fishes in the western Mississippi Basin (Missouri, Arkansas and Red rivers). Pages 363-412 In: Hocutt, C. H. and E. O. Wiley (eds.), The zoogeography of freshwater fishes. John Wiley and Sons, Inc., New York

Cudmore, B. and N. E. Mandrak. 2004. Biological synopsis of grass carp (Ctenopharyngodon idella). Canadian Manuscript Report of Fisheries and Aquatic Sciences $2705.44 \mathrm{pp}$.

Dauwalter, D. C. and J. R. Jackson. 2005. A re-evaluation of U. S. state fish-stocking recommendations for small, private, warmwater impoundments. Fisheries 30 (8):18-28.

Drobish, M. R. (ed.). 2008. Missouri River standard operating procedures for sampling and data collection, Volume 1.3. U.S. Army Corps of Engineers, Omaha District, Yankton, South Dakota.

Freeze, M. and S. Henderson. 1982. Distribution and status of the bighead carp and silver carp in Arkansas. North American Journal of Fisheries Management 2:197200.

Fowler, A. J., D. M. Lodge, and J. F. Hsia. 2007. Failure of the Lacey Act to protect U.S. ecosystems against animal invasions. Frontiers in Ecology and the Environment 5:353-359.

Galat, D. L., C. M. Berry Jr., E. J. Peters, and R. G. White. 2005. Missouri River basin. Pages 427-480 In: Benke, A. and C. Cushing (eds.), Rivers of North America. Elsevier Academic Press, New York.

Guillory, V. and R. D. Gasaway. 1978. Zoogeography of the grass carp in the United States. Transactions of the American Fisheries Society 107:105-112.

Hintze, J. L. 2006. Quick start and help manual NCSS 2000 statistical system for Windows. Number Cruncher Statistical Software, Kaysville, Utah.

Irons, K. S., G. G. Sass, M. A. McClelland, and J. D. Stafford. 2007. Reduced condition factor of two native fish species coincident with invasion of non-native Asian 
carps in the Illinois River, U.S.A. Is this evidence for competition and reduced fitness? Journal of Fish Biology 71:258-273.

Johal, M. S., H. R. Esmaeili, and K. K. Tandon. 2001. A comparison of back-calculated lengths of silver carp from bony structures. Journal of Fish Biology 59:14831493.

Kolar, C. S., D. C. Chapman, W. R. Courtenay, C. M. Housel, J. D. Williams, and D. P. Jennings. 2005. Asian carps of the genus Hypophthalmichthys (Pisces, Cyrprinidae) - a biological synopsis and environmental risk assessment. Report to the U.S. Fish and Wildlife Service. U.S. Geological Survey, LaCrosse, Wisconsin. $184 \mathrm{pp}$.

Mitchell, A. J. and A. M. Kelly. 2006. The public sector role in the establishment of grass carp in the United States. Fisheries 31(3):113-121.

Papoulias, D. M., D. Chapman, and D. E. Tillitt. 2006. Reproductive condition and occurrence of intersex in bighead and silver carp in the Missouri River. Hydrobiologia 571:355-360.

Peters, L. M., M. A. Pegg, and U. G. Reinhardt. 2006. Movements of adult radio-tagged bighead carp in the Illinois River. Transactions of the American Fisheries Society 135:1205-1212.

Pflieger, W. L. 1978. Distribution and status of the grass carp in Missouri streams. Transactions of the American Fisheries Society 107:113-118.

Sampson. S. J., J. H. Chick, and M. A. Pegg. 2009. Diet overlap among two Asian carp and three native fishes in backwater lakes on the Illinois and Mississippi rivers. Biological Invasions 11:483-496.

Schrank, S. J. and C. S. Guy. 2002. Age, growth, and gonadal characteristics of adult bighead carp, Hypophthalmichthys nobilis, in the lower Missouri River. Environmental Biology of Fishes 64:443-450.

Schrank, S. J., C. S. Guy, and J. F. Fairchild. 2003. Competitive interactions between age- 0 bighead carp and paddlefish. Transactions of the American Fisheries Society 132:1222-1228.

Shuman, D. A., G. A. Wanner, R. A. Klumb. 2008. 2007 annual report. Pallid sturgeon population assessment and associated fish community monitoring for the Missouri River: Segments 5 and 6. U.S. Fish and Wildlife Service, Pierre, South Dakota. http://www.fws.gov/greatplainsfishandwildlife/

U.S. Fish and Wildlife Service. 2003. An evaluation of sampling techniques and life history information on bighead carp in the Missouri River below Gavins Point Dam, South Dakota and Nebraska. U.S. Fish and Wildlife Service, Pierre, South Dakota. http://www.fws.gov/greatplainsfishandwildlife/

Wanner, G. A., D. A. Shuman, M. L. Brown, and D. W. Willis. 2007. An initial assessment of sampling procedures for juvenile pallid sturgeon in the Missouri River downstream of Fort Randall Dam, South Dakota and Nebraska. Journal of Applied Ichthyology 23:529-538.

Wanner, G. A. and R. A. Klumb. 2009. Asian Carp in the Missouri River: analysis from multiple Missouri River habitat and fisheries programs. Prepared for the Aquatic Nuisance Species Coordinator, U.S. Fish and Wildlife Service - Region 6, Lakewood, Colorado. U.S. Fish and Wildlife Service, Pierre, South Dakota. http://www.fws.gov/greatplainsfishandwildlife/

Williamson, C. J. and J. E. Garvey. 2005. Growth, fecundity, and diets of newly established silver carp in the middle Mississippi River. Transactions of the American Fisheries Society 134:1423-1430. 